\title{
SULPHURIC AND NITRIC ACID CONCENTRATIONS AND SPIKES ALONG A 200 m DEEP ICE CORE AT D 57 (TERRE ADÉLIE, ANTARCTICA)
}

\author{
by
}

\author{
Françoise Zanolini, Robert J. Delmas and Michel Legrand
}

(Laboratoire de Glaciologie et Géophysique de l'Environnement du C.N.R.S., B.P. 96, 38402 St.-Martin-d'Hères Cedex, France)

\begin{abstract}
D 57 station in Terre Adelie lies between the coast and the central Antarctic plateau. A $200 \mathrm{~m}$ ice core was recovered in summer $1980-81$ at this location and analyzed by an electroconductometric method to detect exceptional acid levels linked to fallout from major volcanic eruptions. Several signals were indeed found. The corresponding ice-core sections were then analyzed for mineral acids $\left(\mathrm{H}_{2} \mathrm{SO}_{4}\right.$ and $\mathrm{HNO}_{3}$ ). We detected several large volcanic events, in particular two eruptions identified as Tambora (1815) and Galunggung (1822). The background concentration of sulphate was found to be relatively low (about $0.5 \mu \mathrm{eq} \mathrm{^{-1 }}$ ). On the other hand nitrate values were higher than at coastal or central Antarctic locations (except for the South Pole). Two spikes were found in the nitrate profile at depths of 140 and $148 \mathrm{~m}$. It is thought that they could be either linked to the 1604 and 1572 supernovae Kepler and Tycho or correspond to epochs of particularly high solar activities. With the aid of these sulphate and nitrate exceptional events, a dating of the D 57 ice core can now be proposed which corresponds to a mean snow accumulation rate of $22 \mathrm{~cm}$ of ice equivalent per year over the last four centuries.
\end{abstract}

\section{INTRODUCTION}

The surface of Terre Adelie can be represented by a continuous and gentle slope from the coast up to the central Antarctic plateau (elevation $>3000 \mathrm{~m}$ ). D 57 station is located at an elevation of $2050 \mathrm{~m}$ and at a distance of $200 \mathrm{~km}$ from the sea (lat $68^{\circ} 11^{\prime} \mathrm{S}$, long $137^{\circ} 33^{\prime} \mathrm{E}$ ). Thus this site occupies an intermediate position between the coastal areas where the snow accumulation rate is high and the plateau where it is very small. The decreasing influence of the marine air masses towards the interior is clearly reflected in the snow chemistry. Glaciochemical studies have already been performed at coastal sites (Aristarain and others 1982, Legrand and Delmas 1985) or at more central Antarctic locations such as the South Pole (Delmas and others 1982, Legrand and Delmas 1984), Dome C (Legrand 1980) or Byrd station (Herron 1982). It was therefore deemed of interest to look at the chemical composition of the trace impurities deposited at locations such as D 57. Drilling to a depth of $200 \mathrm{~m}$ was carried out at D 57 during summer 1980-81 and a core recovered for climatic glaciological and glaciochemical studies. In this paper we report on the measurements of $\mathrm{H}^{+}$, $\mathrm{SO}_{4}^{2-}$ and $\mathrm{NO}_{3}^{-}$ions performed on selected sections of the D 57 ice core between 47 and $155 \mathrm{~m}$ from the surface.

\section{DATING OF THE CORE}

As the snow accumulation rate in this region of Terre Adélie is relatively irregular (Young and others 1982), the dating of the D 57 ice core was not accurately known before these studies. The accumulation rate at D 57 was estimated to be about $41 \pm 9 \mathrm{~g} \mathrm{~cm}^{-2} \mathrm{a}^{-1}$ from stake measurements made over a period of $10 \mathrm{a}$. The age at the bottom of the core was then calculated to be around $\mathrm{AD} 1600$. Ice-flow and model calculations conducted more recently indicate ages significantly greater than this preliminary estimate (Barnola unpublished). We shall see that a combination of the model with the glaciochemical data reported in this paper allows us to present a new aspect of the dating of this core. Until the discussion of the $\mathrm{H}_{2} \mathrm{SO}_{4}$ and $\mathrm{HNO}_{3}$ exceptional events recorded in this core, the following provisional dates can be given (note that further on in this paper all depth values will be in metres of ice equivalent throughout): $A D$ 1880 at $50 \mathrm{~m}, \mathrm{AD} 1790$ at $100 \mathrm{~m}$, and $\mathrm{AD} 1430$ at $150 \mathrm{~m}$.

\section{ANALYTICAL METHODS}

One of the major primary aims of the glaciological studies at D 57 being the search for past volcanic deposits, continuous conductometric measurements were made in the field according to a method developed by Hammer (1980). A detailed description of the equipment has been given by Zanolini (1983)* and Delmas and others (in press) Severa core sections presenting high conductivity levels were detected and selected for further chemical measurements. Moreover a long sequence $(6 \mathrm{~m}$ at about $50 \mathrm{~m}$ depth) was analyzed in order to obtain the background values of the ions studied in the absence of exceptional events.

The determination of trace elements in firn or ice cores necessitates the use of stringent contamination-free techniques. The cores were stored in cold rooms until their analysis in the Grenoble laboratories. The selected sections were cut an recorded following a procedure described by Legrand and others (1984). Only the inner part of each ice (or firn) core was kept for chemical determinations. Acidity was determined by titration to $\pm 0.2 \mu$ eq $1^{-1}$ (Legrand and others 1982). Sulphate and nitrate ions were measured (generally $\pm 10 \%$ except for lowest concentrations) by ion chromatography with the aid of a Dionex apparatus (Model 10). For acidity measurements, a relatively constant ( 0.8 to $1.2 \mu$ eq $\left.1^{-1}\right)$ blank value was observed but not subtracted from the acidity data This blank is not linked to a contamination problem but rather to the titrimetric procedure itself as discussed by Legrand and others (1982).

\section{RESULTS AND DISCUSSIONS}

The electrical conductivity of the ice core was first measured in the field and then confirmed in Grenoble in the cold rooms $\left(-15^{\circ} \mathrm{C}\right)$. A nearly continuous record was obtained from a depth of 40 to $155 \mathrm{~m}$, the firn cores being unsuitable for measuring with our equipment.

All conductometric profiles are reported elsewhere (Zanolini 1983). They exhibit large variations and peaks. These peaks were assumed to be linked to rapid increases of the acidity of the ice. Twelve of them (listed in Table I) were particularly pronounced and were analyzed chemically after recoring. It is worth noting that their length is generally from 1 to 2 a. The results of the chemical measurements are plotted as a function of depth (Figs 1, 2 and 3). It was not always possible to obtain continuous profiles, either because portions of the ice cores were broken or missing or because a few meltwater samples were lost or contaminated during laboratory work. As an example, all alkaline samples were considered as definitely contaminated (this point is explained in Legrand and others 1982).

It has already been discussed and demonstrated elsewhere (Aristarain and others 1982, Delmas and others 1982, Legrand

* In this report the depths were erroneously given in metres of ice equivalent. They must be read as metres below the surface. 
TABLE I. THE PEAKS OF CONDUCTIVITY SELECTED FOR CHEMICAL STUDIES ALONG THE D 57 ICE CORE). The mean current (averaged over segments $0.2 \mathrm{~m}$ long) obtained from conductometric measurements gives an indication of the strength of the signal. The background variability of the current was in the range from 0.5 to $1 \mu \mathrm{A}$.)

\begin{tabular}{lcccccccccccc} 
Peak no & 1 & $2 *$ & 3 & 4 & 5 & 6 & 7 & 8 & 9 & 10 & 11 & 12 \\
\hline $\begin{array}{l}\text { Depth } \\
\text { interval }\end{array}$ & 48.00 & 49.49 & 52.80 & 82.57 & 88.67 & 101.26 & 110.09 & 111.69 & 117.76 & 120.25 & 126.44 & 153.99 \\
$\begin{array}{l}(\mathrm{m}) \\
\begin{array}{l}\text { Mean } \\
\text { current }(\mu \mathrm{A})\end{array}\end{array}$ & 48.37 & 50.41 & 53.02 & 83.11 & 89.99 & 101.56 & 110.76 & 111.96 & 118.47 & 120.49 & 126.63 & 155.26 \\
\end{tabular}

*Double peak

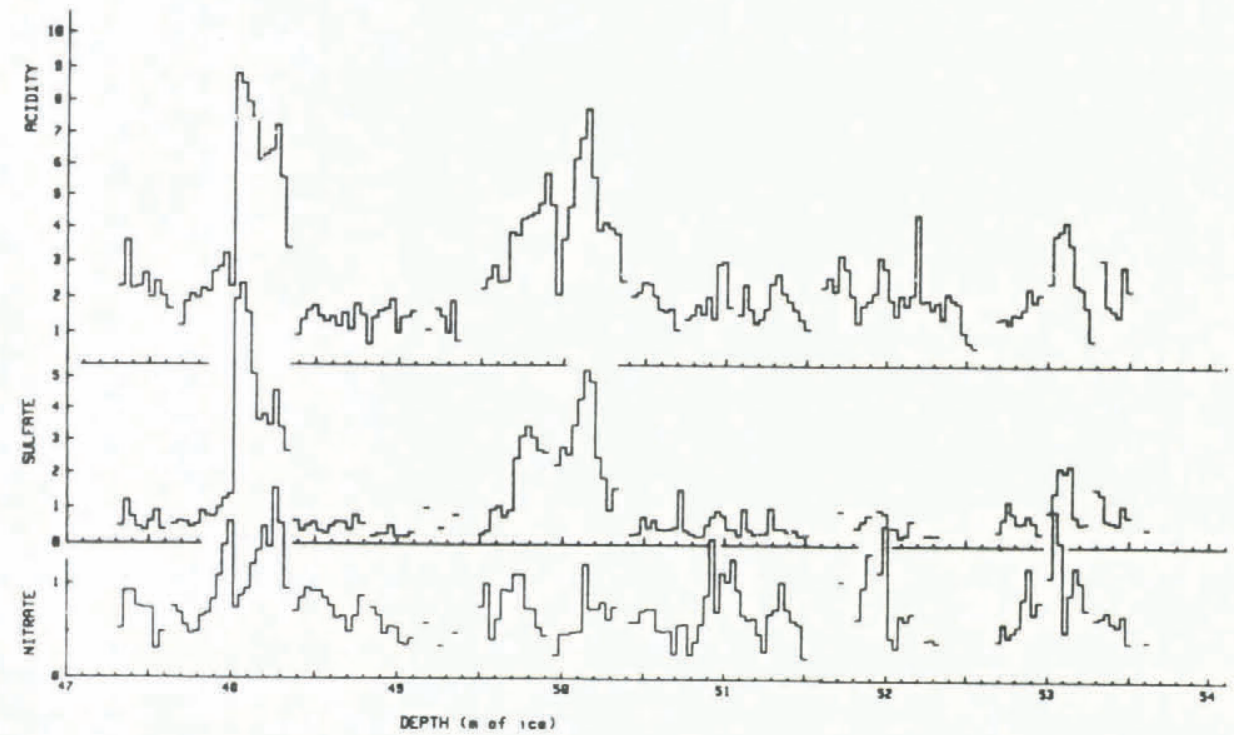

Fig.1. D 57 station. Acidity, sulphate and nitrate profiles (in $\mu$ eq $1^{-1}$ ) from 47.3 to $53.6 \mathrm{~m}$ (metres below the surface) deep.

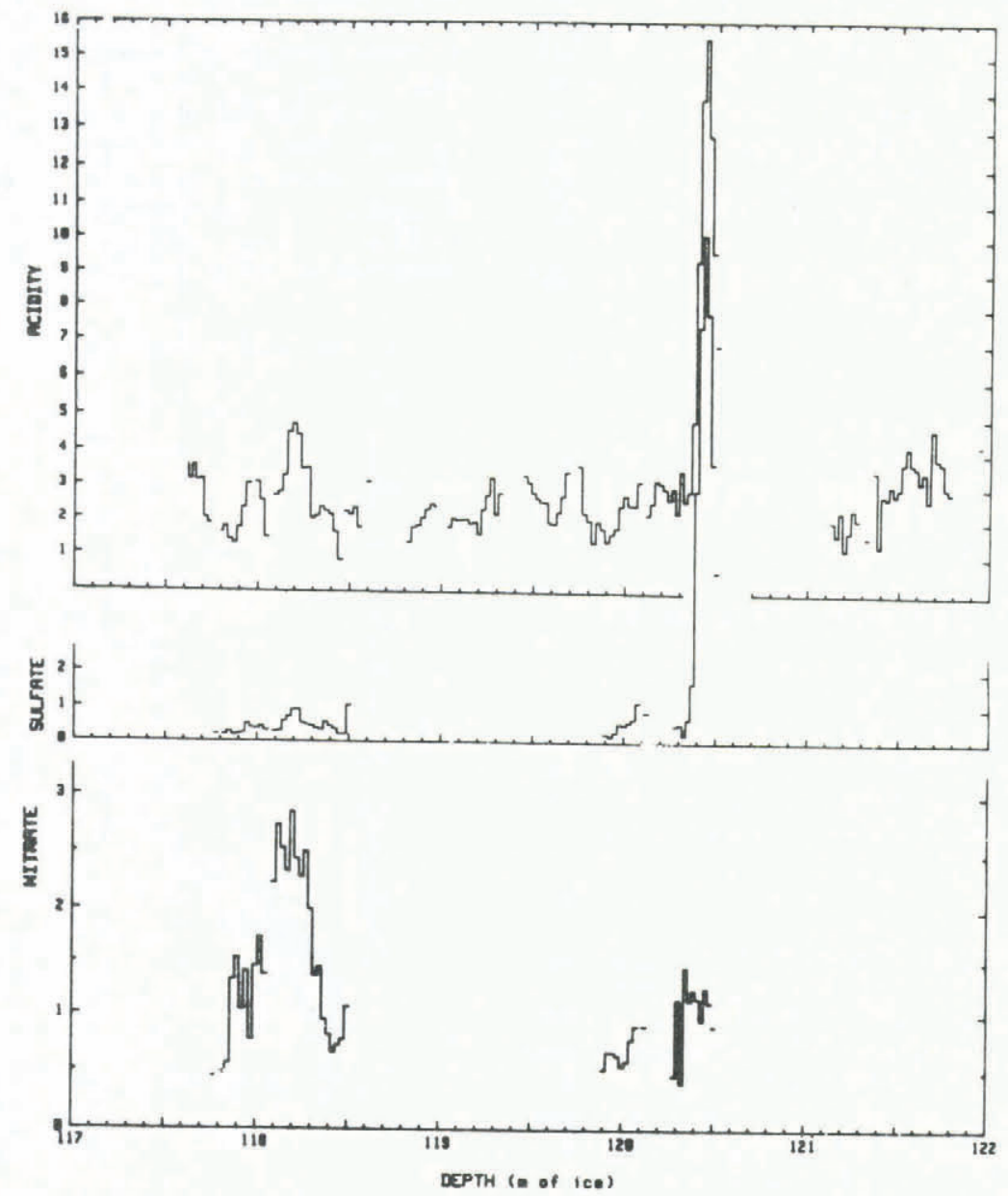

Fig.2. D 57 station. Acidity, sulphate and nitrate profiles (in $\mu$ eq $\mathrm{I}^{-1}$ ) between 117.7 and $121.8 \mathrm{~m}$ (metres below the surface) deep. 


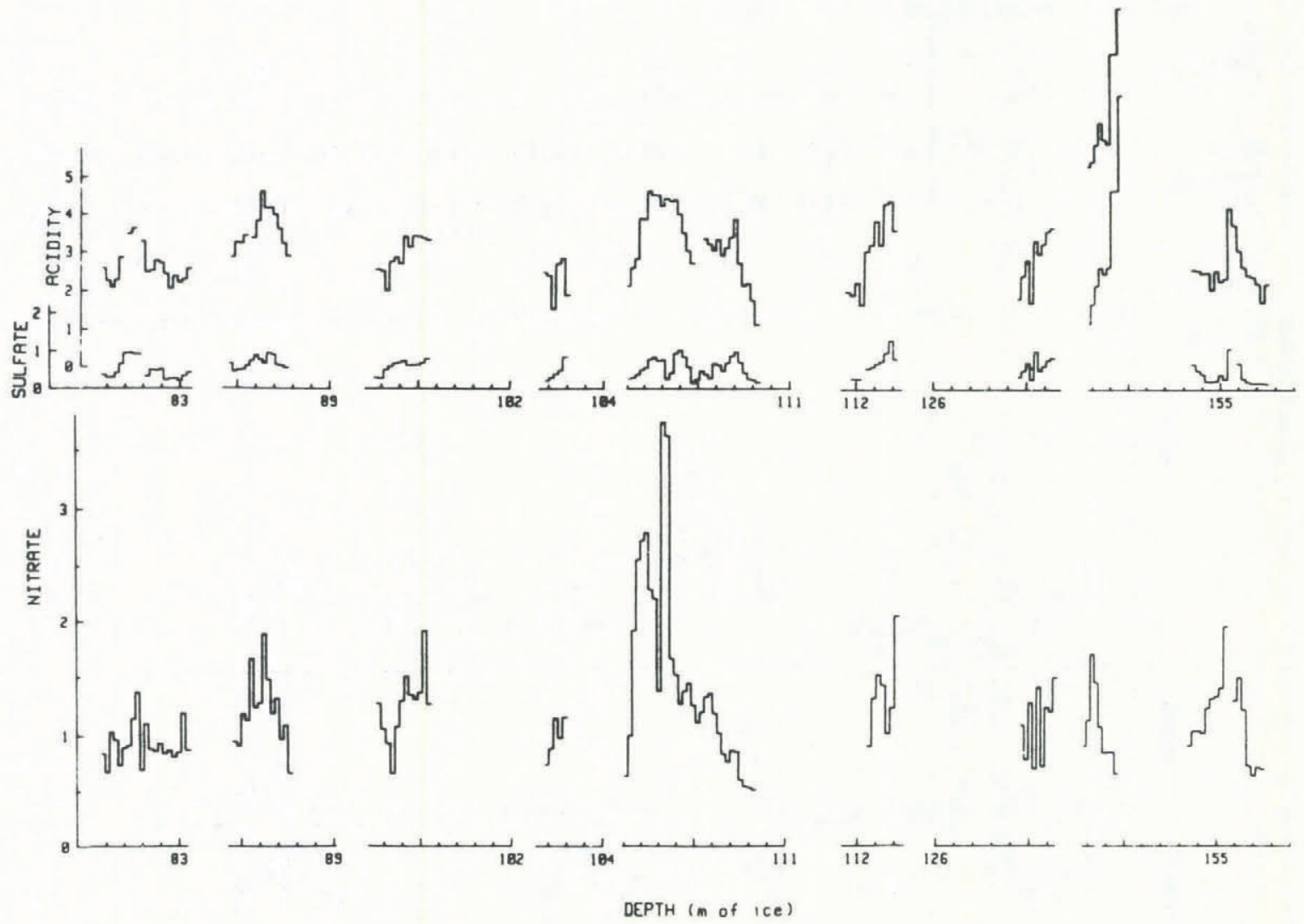

Fig.3. D 57 station. Acidity, sulphate and nitrate concentrations (in $\mu$ eq $\mathrm{I}^{-1}$ ) in different core sections.

and Delmas 1984) that, except at the coast, sulphate and nitrate are mainly present in Antarctic precipitation as $\mathrm{H}_{2} \mathrm{SO}_{4}$ ("excess sulphate") and $\mathrm{HNO}_{3}$, respectively. Another possible acid is $\mathrm{HCl}$ ("excess chloride"), which has not been measured systematically in this study but has been estimated on a few chromatograms. It appears that its contribution is always weak in this geographical region as confirmed by the glaciochemical studies reported by Legrand and Delmas (1985) in Terre Adélie.

We can therefore write the following equation (the concentrations in square brackets are in $\mu$ eq $1^{-1}$ )

$$
\left[\mathrm{H}^{+}\right]=\left[\mathrm{SO}_{4}^{2-}\right]+\left[\mathrm{NO}_{3}\right]+b,
$$

where $\mathrm{b}$ is the blank value (see section 3). Acidity may be slightly neutralized by ammonia (Legrand and Delmas 1984) and neutral salt formed. In this case we would have

$$
\left[\mathrm{H}^{+}\right]<\left[\mathrm{SO}_{4}^{2-}\right]+\left[\mathrm{NO}_{3}\right]+\text { b. }
$$

On the other hand, the presence of $\mathrm{HCl}$ would lead to

$$
\left[\mathrm{H}^{+}\right]>\left[\mathrm{SO}_{4}^{2-}\right]+\left[\mathrm{NO}_{3}\right]+\text { b. }
$$

In order to check out these two last eventualities, all acidity, sulphate and nitrate data were analyzed mathematically. A multiple correlation coefficient of 0.948 was obtained for the multiple regression of Equation (4)

$$
\left[\mathrm{H}^{+}\right]=\mathrm{s}\left[\mathrm{SO}_{4}^{2-}\right]+\mathrm{n}\left[\mathrm{NO}_{3}\right]+\mathrm{b} .
$$

The calculation gave $\mathrm{s}=1.00, \mathrm{n}=0.95$, and $\mathrm{b}=0.97$. This demonstrates that generally we have unneutralized $\mathrm{H}_{2} \mathrm{SO}_{4}$ and $\mathrm{HNO}_{3}$ in snow, (in particular in the sulphate and nitrate "peaks"), the variance of the acidity being explained almost completely by the sum of these two acids. The term b= 0.97 falls within the observed fluctuations of the experimental blank. This also means that the $\mathrm{HCl}$ content is generally very low. These results are plotted in Figure 4 (acidity as a function of sulphate + nitrate). The observed scattering may be explained partly by the sum of the analytical errors in the determination of ions (which increases at low concentrations), and partly by the presence of $\mathrm{NH}_{4}^{+}$or $\mathrm{HCl}$ in small amounts as explained earlier (Equations (2) and (3), respectively).

When looking at the depth profiles in Figure 1, it can be seen that both sulphate and nitrate exhibit fluctuations which resemble seasonal variations. However there is apparently no link between the two. Sulphate profiles are relatively regular but are sporadically disturbed by strong perturbations of a duration of 1 to 2 a. Such observations

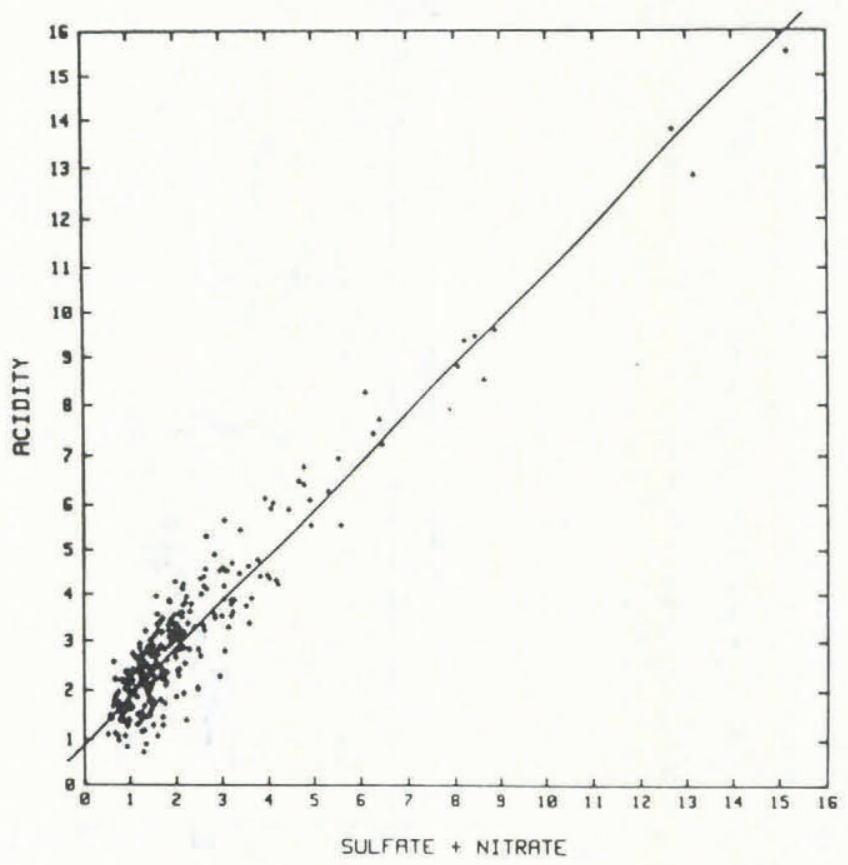

Fig.4. Acidity as a function of sulphate plus nitrate (in $\mu$ eq $\left.1^{-1}\right)$. 
The number of volcanic events recorded in this core is therefore very limited. This observation corresponds with the general discussion of volcanic deposits in Antarctic snow (Delmas and others in press) where it was shown that D 57, due to its relatively high snow-accumulation rate, is not a very suitable site for palaeovolcanic studies. Volcanic signals are probably less clearly recorded here than on the Antarctic plateau (Legrand and Delmas 1985).

By means of electroconductometric measurements we also detected acid events which were found to depend mainly on $\mathrm{HNO}_{3}$ (Zanolini 1983). The two strongest are located between depths of from 110.2 to 110.4 and from 118.1 to $118.3 \mathrm{~m}$ (i.e. durations of about one year). They differ markedly (by nearly $1.5 \mu$ eq $1^{-1}$ ) from the seasonal variations of nitrate at these depths. The distance between these two prominent events $(\sim 7.9 \mathrm{~m}$ of ice, i.e. $\sim 35$ a) may suggest that they could be linked with the two supernovae Kepler and Tycho which are known to have occurred in $\mathrm{AD} 1604$ and $\mathrm{AD}$ 1572. The possible influence of these outbursts on the nitrate fallout in Antarctica was first proposed by Rood and others (1979) who observed two important spikes around these dates in the nitrate profile obtained at the South Pole.

This discovery was strongly questioned by several authors (Stothers 1980, Risbo and others 1981) with theoretical as well as experimental arguments. Stothers proposed an alternative explanation: the influence of giant solar flares on the atmospheric background concentrations of $\mathrm{HNO}_{3}$. $\mathrm{He}$ caiculated that the high-energy radiation produced during these events is sufficient to form large amounts of $\mathrm{HNO}_{3}$. He emphasized that giant solar flares occur preferentially during periods of intense solar activity and that two such periods are known to have occurred between $\mathrm{AD}$ 1565-1585 and $\mathrm{AD}$ $1605-1630$, i.e. in the same epoch as the two supernovae. The next largest solar maxima were in $\mathrm{AD}$ 1778-1788 and AD 1947-1959. In the absence of convincing theoretical calculations regarding the possibility of the formation of large amounts of $\mathrm{HNO}_{3}$ by supernovae and in the absence of finding $\mathrm{HNO}_{3}$ spikes at the two other epochs of high solar activity, our interpretation concerning the two $\mathrm{HNO}_{3}$ peaks of our profile at 110.3 and $118.2 \mathrm{~m}$ depth cannot be regarded as definitive.

Nevertheless the dating obtained using the dates of the two supernovae presents some very attractive aspects. Together with the signals of Tambora and Galunggung (1815 and 1822), they allow us to propose a new and coherent interpretation for the dating of this ice core. If we consider these four horizons, we can calculate the snow-accumulation rates reported in Table II (the solar flare hypothesis would give similar but less accurate results).

The model proposed by Barnola (unpublished) gave a mean accumulation of $29.4 \mathrm{~cm}$ of ice equivalent $\mathrm{a}^{-1}$ over four centuries. Our value is nearly $25 \%$ lower, just entering in the limits of the results of the model calculations. If we may be relatively confident with our dating until 1800 $A D$, we must agree that the dating of the lower part of the core is very uncertain either by using references horizons or model estimations. By using this new dating, we can locate the Maunder minimum between depths of 80 and $105 \mathrm{~m}$. Rood and others (1979) assumed that the nitrate levels in polar ice might be reduced during this time period in relation to the particularly low solar activity and claimed they had detected this effect in South Pole snow (see also Parker and others 1982). Our nitrate data from depths around 83, 89

TABLE II. ACCUMULATION RATES DEDUCED FROM THE SULPHATE AND NITRATE HORIZONS

Reference levels

Mean accumulation rate $\left(\mathrm{cm}\right.$ of ice equivalent $\mathrm{a}^{-1}$ )

Surface - Tambora $(50.2 \mathrm{~m})$

Galunggung (48.2 m) - Tambora

Surface - Kepler SN (110.3 m)

Kepler SN - Tycho SN (118.2 m) and $102 \mathrm{~m}$ (indeed very limited, Fig.3) are not lower than the background value at the beginning of the nineteenth century $(50 \mathrm{~m})$. The solar influence on the nitrate level of Antarctic snow is therefore not confirmed, as already observed for cycles of 11 a.

\section{CONCLUSION}

The detailed chemical study of a deep Antarctic ice core is a very time-consuming task. Here we have used a physico-chemical method to detect the most interesting levels of the D 57 ice core and to analyze a limited set of samples for acidity, sulphate and nitrate. With the aid of these measurements we have obtained interesting features concerning the temporal variability of these compounds in snow over approximately six centuries. A limited number of chemical spikes were found and identified but those of nitrate need to be confirmed by further glaciochemical work at other Antarctic sites.

\section{ACKNOWLEDGMENTS}

We are indebted to $\mathrm{J} M$ Barnola, $P$ Duval and $\mathrm{D}$ Raynaud for valuable scientific discussions, to $\mathrm{M} \mathrm{C}$ Mieulet and $\mathrm{J}$ Borde for computing the data and to $\mathrm{M}$ Creseveur for the conductometric measurements in the field. This investigation was partially financed by Terres Australes et Antarctiques Françaises and Centre National de la Recherche Scientifique (through the Programme Interdisciplinaire de Recherche sur la Prévision et la Surveillance des Eruptions Volcaniques (PIRPSEV) and Programme Interdisciplinaire de Recherche sur l'Environnement (PIREN).

\section{REFERENCES}

Aristarain A J, Delmas R J, Briat M 1982 Snow chemistry on James Ross Island (Antarctic Peninsula). Journal of Geophysical Research 87(C13): 11004-11012

Barnola J M Unpublished Étude des variations passées du $\mathrm{CO}_{2}$ atmosphérique à partir de l'analyse de l'air piégé dans la glace. Détermination de la teneur pré-industrielle; étude de la transition dernier âge glaciaire-Holocène. (Thèse de Troisième Cycle, Université de Grenoble, 1984)

Delmas R J, Boutron C 1980 Are the past variations of the stratospheric sulfate burden recorded in central Antarctic snow and ice layers? Journal of Geophysical Research 85(C10): 5645-5649

Delmas R J, Briat M, Legrand M 1982 Chemistry of south polar snow. Journal of Geophysical Research 87(C6): 4314-4318

Delmas $\mathrm{R} J$, Legrand $\mathrm{M}$, Aristarain A J, Zanolini $\mathrm{F}$ In press Volcanic deposits in Antarctic snow and ice. Journal of Geophysical Research

Hammer C U 1980 Acidity of polar ice cores in relation to absolute dating, past volcanism, and radio-echoes. Journal of Glaciology 25(93): 359-372

Herron M M 1982 Impurity sources of $\mathrm{F}^{-}, \mathrm{Cl}^{-}, \mathrm{NO}_{3}^{-}$and $\mathrm{SO}_{4}{ }^{2-}$ in Greenland and Antarctic precipitation. Journal of Geophysical Research 87(C4): 3052-3060

Legrand M 1980 Mesure de l'acidité et de la conductivitc électrique des précipitations antarctiques. Centre National de la Recherche Scientifique. Laboratoire de Glaciologic et Géophysique de l'Environnement. Publication 316

Legrand M, Delmas R J 1984 The ionic balance of Antarctic snow: a 10-year detailed record. Atmospheric Environment 18(9): 1867-1874

Legrand M, Delmas R J 1985 Spatial and tempora variations of snow chemistry in Terre Adélie (East Antarctica). Annals of Glaciology 7: 20-25

Legrand M, Aristarain A J, Delmas A J 1982 Acid titration of polar snow. Analytical Chemistry 54: 1336-1339

Legrand M, De Angelis M, Delmas R J 1984 Ion chromatographic determination of common ions at ultratrace levels in Antarctic snow and ice. Analytica Chimica Acta 156: 181-192

Newhall C G, Self S 1982 The volcanic explosivity index (VEI): an estimate of explosive magnitude for historical volcanism. Journal of Geophysical Research 87(C2): $1231-1238$ 
Parker B C, Zeller E J, Gow A J 1982 Nitrate fluctuations in Antarctic snow and firn: potential sources and mechanisms of formation. Annals of Glaciology 3: 243-248

Risbo T, Clausen H B, Rasmussen K L 1981 Supernovae and nitrate in the Greenland ice sheet. Nature 294(5842): 637-639

Rood R T, Sarazin C L, Zeller E J, Parker B C 1979 Xor $y$-rays from supernovae in glacial ice. Nature 282(5740): 701-703

Stothers R 1980 Giant solar flares in Antarctic ice. Nature 287(5780): 365

Young N W, Pourchet M, Kotlyakov V M, Korolev P A, Dyugerov M B 1982 Accumulation distribution in the IAGP area, Antarctica: $90^{\circ} \mathrm{E}-150^{\circ}$ E. Annals of Glaciology 3: 333-338

Zanolini F 1983 Conductimétrie et chimie de la glace à D 57 (Terre Adélie). Application à la recherche du paléovolcanisme. Centre National de la Recherche Scientifique. Bulletin PIRPSEV 76

Zeller E J, Parker B C 1981 Nitrate ion in Antarctic firn as a marker for solar activity. Geophysical Research Letters 8(8): 895-898 